\title{
Pengaruh Augmented Reality Senjata Dewata Nawa Sanga sebagai Media Pembelajaran Interaktif Terhadap Pembelajaran Agama Hindu Di SD Negeri 2 Pererenan
}

\section{Putu Adi Saskara ${ }^{1}$}

${ }^{1}$ Program Studi Komunikasi Hindu

Fakultas Dharma Duta, Institut Hindu Dharma Negeri Denpasar

Abstract

Keywords
Information and communication technology seems to have become a function of books, teachers and teaching systems that were previously conventional. The conventional learning system at this time makes communication between teachers and students less effective due to the lack of attention of students to the lessons explained by the teacher and students quickly saturated during the lesson. Based on the background of the problem, the researcher formulated a number of problem formulations namely 1) How to build an application that can facilitate students in learning and knowing the weapons of Dewata Nawa Sañga at SD Negeri 2 Pererenan, Pererenan, Mengwi, Badung? 2) What is the function of augmented reality weapons of Dewata Nawa Sañga as a communication media for Hindu religious education at SD Negeri 2 Pererenan, Pererenan, Mengwi, Badung? 3) How is the impact of augmented reality weapons of Dewata Nawa Sanga on learning Hinduism in SD Negeri 2 Pererenan, Pererenan, Mengwi Badung?

The theory used in this study is structural-functional theory and persuasive communication theory. This type of analysis is research and development with the types of qualitative and quantitative data as supporters. To determine the informants in the field the author uses purposive sampling technique. Data collection methods used are observation, interviews, documentation and library studies.

The results of the research obtained were the formation of an Android-based Augmented Reality Dewata Nama Sanga application. The function of this application as a learning media are: attention function, affective function, cognitive function, compensatory function, and motivating interests or actions, presenting information, and giving instructions. The impact is increasing student interest in learning, improving student learning outcomes with the percentage of $80.25 \%$ for the control class and $82.4 \%$ for the experimental class.

augmented reality, goddess of the name san'ga, interactive learning media.

\footnotetext{
${ }^{1}$ adi_saskara@ihdn.ac.id
} 


\section{PENDAHULUAN}

Teknologi informasi dan komunikasi saat ini sangat berkembang di masyarakat. Umumnya teknologi informasi adalah sebuah teknologi yang dipergunakan untuk mengelola data, meliputi didalamnya: memproses, mendapatkan, menyusun, menyimpan, memanipulasi data dengan berbagai macam cara dan prosedur guna menghasilkan informasi yang berkualitas dan bernilai guna tinggi. Perkembangan teknologi informasi dan komunikasi pun terus meningkat seiring dengan meningkatnya kebutuhan manusia. Dengan adanya teknologi informasi dan komunikasi dapat memudahkan kita untuk belajar dan mendapatkan informasi yang kita butuhkan dari mana saja, kapan saja, dan dari siapa saja.

Teknologi informasi dan komunikasi seakan telah mendarah daging didalam diri setiap manusia di era ini, teknologi informasi dan komunikasi yang telah mengglobal mampu mencakupi segala aspek yang ada dalam kehidupan. Seiring dengan kemajuan teknologi yang mengglobal telah terpengaruh dalam segala aspek kehidupan baik di bidang ekonomi, politik, kebudayaan, seni dan bahkan di dunia pendidikan. Dalam bidang pendidikan, teknologi informasi dan komunikasi banyak memiliki peranan. Kemajuan teknologi adalah sesuatu yang tidak bisa kita hindari dalam kehidupan ini, karena kemajuan teknologi akan berjalan sesuai dengan kemajuanm ilmu pengetahuan. Teknologi informasi seakan telah menjadi pengalihfungsian buku, guru dan sistem pengajaran yang sebelumnya masih bersifat konvensional. Teknologi informasi menyebabkan ilmu pengetahuan menjadi kian berkembang dan berkembang. Setiap inovasi diciptakan untuk memberikan manfaat positif bagi kehidupan manusia. Memberikan banyak kemudahan, serta sebagai cara baru dalam melakukan aktifitas manusia. Khusus dalam bidang pendidikan yang mempunyai banyak kategori seperti pendidikan IPA, IPS, Agama dan sebagainya, teknologi informasi sudah menikmati banyak manfaat yang dibawa oleh inovasi-inovasi yang telah dihasilkan dalam dekade terakhir ini.

Dalam dunia pendidikan, pendidikan agama mempunyai peran yang sangat penting yang dimaksudkan untuk membentuk peserta didik menjadi manusia yang beriman dan bertakwa kepada Tuhan Yang Maha Esa dan berakhlak mulia serta peningkatan potensi spritual. Akhlak mulia mencakup etika, budi pekerti, dan moral sebagai perwujudan dari pendidikan agama. Peningkatan potensi spritual mencakup pengenalan, pemahaman, dan penanaman nilai-nilai keagamaan, serta pengamalan nilai-nilai tersebut dalam kehidupan individual ataupun kolektif kemasyarakatan. Peningkatan potensi spritual tersebut pada akhirnya bertujuan pada optimalisasi berbagai potensi yang dimiliki manusia yang aktualisasinya mencerminkan harkat dan martabatnya sebagai makhluk Tuhan.

Dunia pendidikan agama khususnya di Indonesia yang memiliki beragam kepercayaan dan budaya, pendidikan agama di bagi menjadi beberapa bagian sesuai dengan kepercayaan masing-masing pemeluk agama yang diantaranya ada pendidikan agama Hindu, Islam, Kristen Protestan, 
Kristen Katolik, dan pendidikan agama Buddha. Pendidikan agama Hindu merupakan usaha yang dilakukan secara terencana dan berkesinambungan dalam rangka mengembangkan kemampuan peserta didik untuk memperteguh keimanan dan ketakwaan kepada Tuhan Yang Maha Esa dan berakhlak mulia, serta peningkatan potensi spiritual sesuai dengan ajaran agama Hindu. Pendidikan agama Hindu di SD Negeri 2 Pererenan, Kecamatan Mengwi, Kabupaten Badung memiliki banyak ajaran-ajaran yang di ajarkan guru kepada peserta didiknya, salah satu pelajaran tersebut tentang Dewata Nawa Sañga.

SD Negeri 2 Pererenan merupakan sekolah yang bertempat di Desa Pererenan, Kecamatan, Mengwi, Kabupaten Badung, yang memiliki jumlah total siswa 149 orang pada tahun ajaran 2018/2019 dan sewaktu-waktu bisa berubah. Sekolah Dasar Negeri 2 Pererenan adalah salah satu sekolah dasar yang siswa kelas 5 dan kelas 6 sudah semuanya memakai laptop dalam proses belajar mengajar. Secara umum, dalam proses belajar mengajar di SD Negeri 2 Pererenan. hampir semua kegiatan belajar mengajar menggunakan media pembelajaran yang di bantu oleh teknologi pada saat ini, terkecuali pelajaran agama Hindu yang masih menggunakan metode pembelajaran konvensional, walaupun demikian sekolah SD Negeri 2 Pererenan belum mengenal perkembangan teknologi terbaru pada saat ini seperti, Augmented Reality, Video Reality dan teknologi lainnya.

Pada era globalisasi ini kebanyakan peserta didik akan merasa jenuh dan bosan dengan metode pembelajaran tersebut yang bersifat monoton, dan kurang menarik minat belajar, siswa pada saat ini lebih suka, lebih suka bermain, menonton video, ataupun mengakses sesuatu yang belum mereka ketahui, yang lebih parah siswa kebanyakan suka mengabaikan gurunya pada saat pembelajaran berlangsung, sehingga pelajaran menjadi kurang efektif, berbeda dengan siswa sekolah dasar sebelum era globaliasi yang pada kondisi lapangannya guru masih bisa mendominasi kelas, dengan sifat keras mereka sehingga siswa, ingin tidak ingin harus mengikuti pelajaran yang diajarkan guru kepada siswa tersebut.

Sedangkan pada era dengan
peraturan pemerintah sekarang,
siswalah yang mendominasi,
dikarenakan guru tidak boleh melakukan tidak kekerasan fisik maupun non fisik terhadap peserta didiknya seperti, memukul, memarahi dengan suara keras, menghina dan lain sebagainya. Sehingga menyebabkan guru harus mendekati mereka dengan sistem pembelajaran yang dapat menarik minat siswa tersebut. Apalagi pihak pemerintah kabupaten badung sudah memberikan alat bantu pembelajaran ke seluruh sekolah dasar di kabupaten badung yang dapat menunjang pendidikan yang berupa teknologi yang mempermudah pembelajaran beserta tenaga Information Technology (IT) .

Berdasarkan latar belakang masalah dan kondisi lapangan tersebut, peneliti merasa tertarik membangun aplikasi pembelajaran Augmented Reality Senjata Dewata Nawa San ga serta meneliti dampak yang ditimbulkan. Dalam mempelajari tentang bagaimana bentuk dan arti dari senjata Dewata Nawa Sañga dalam Augmented Reality yang keberadaan alat pembelajaran Dewata Nawa Sañga dirasa susah untuk 
melihat bentuk aslinya maka dirasa perlu menggunakan teknologi informasi dalam menciptakan sebuah sistem belajar yang menarik dan inovatif yang nantinya bisa merubah cara belajar tentang bagaimana bentuk dan arti dari senjata Dewata Nawa Sañga itu sendiri di SD Negeri 2 Pererenan, Pererenan, Mengwi, Badung.

Augmented Reality itu sendiri merupakan teknologi yang menggabungkan benda maya dua dimensi dan ataupun tiga dimensi ke dalam sebuah lingkungan nyata tiga dimensi lalu memproyeksikan bendabenda maya tersebut dalam waktu nyata. Augmented Reality hanya menambahkan atau melengkapi kenyataan, tidak seperti realitas maya yang sepenuhnya menggantikan kenyataan. Penerapan teknologi informasi di bidang multimedia memiliki daya tarik tersendiri salah satunya menggunakan Augmented Reality sebagai salah satu aplikasi multimedia dalam mempermudah memperkenalkan atau mempelajari senjata dari Dewata Nawa Sañga dan maknanya, karena akan lebih interaktif dan menarik.

Peneliti berharap penerapan Augmented Reality ke dalam senjata Dewata Nawa San ga diharapkan mampu mempermudah serta membawa dampak yang positif bagi siswa SD Negeri 2 Pererenan, Pererenan, Mengwi, Badung dalam mempelajari arti dan fungsi serta memahami bentuk senjata Dewata Nawa Sanga.

\section{METODE}

Metode penelitian adalah langkahlangkah kerja yang harus dilakukan di dalam suatu penelitian, untuk memperoleh gambaran permasalahan dan untuk menentukan langkah-langkah dalam suatu penelitian, sehingga permasalahan dapat dipecahkan. Metode penelitian memiliki peranan yang sangat penting dalam melakukan sebuah penelitian karena penentuan tujuan penelitian bergantung dari ketetapan peneliti dalam menggunakan metode penelitian,dan juga mengingat bahwa suatu karya ilmiah harus bisa dipertanggungjawabkan secara ilmiah. Penggunaan metode penelitian yang sangat penting maka dalam penelitian ini akan digunakan beberapa metode penelitian yaitu lokasi penelitian, jenis penelitian,atau menggunakan paradigm penelitian, teknik pengumpulan data, jenis sumber data, instrument penelitian, analisis data.

Dalam penelitian Pengaruh Augmented Reality Senjata Dewata Nawa San ga Sebagai Media Pembelajaran Interaktif Terhadap Pembelajaran Agama Hindu Di SD Negeri 2 Pererenan. Metode penelitian yang di pakai adalah penelitian kualitatif dan kuantitatif dengan teknik pengumpulan data melalui observasi, wawancara terstruktur dan tak terstruktur, dokumentasi, studi kepustakaan serta metode tes untuk dampak Augmented Reality Senjata Dewata Nawa San ga terhadap hasil belajar siswa. Dalam penelitian ini penentuan informan yang dipilih secara purposive sampling dengan dikenal juga dengan sampling pertimbangan-pertimbangan tertentu di dalam pengambilan sampelnya atau penentuan sampel untuk tujuan tertentu. Hanya mereka yang ahli patut memberikan pertimbangan untuk pengambilan sampel yang diperlukan. Hasil analisis data tersebut kemudian dijabarkan secara sistematis dan efisien, sehingga diharapkan mudah dipahami 
dan dapat memberikan kejelasan optimal bagi pembaca.

\section{HASIL DAN PEMBAHASAN}

Membangun sebuah aplikasi tidaklah mudah, ada beberapa hal yang harus dilakukan pertama adalah perancangan sistem. Perancangan sistem pada penelitian menggunakan UML (Unified Modelling Language). Diagram-diagram

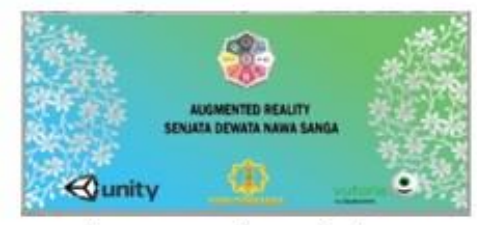

Gambar 1. Tampilan Splash Screen

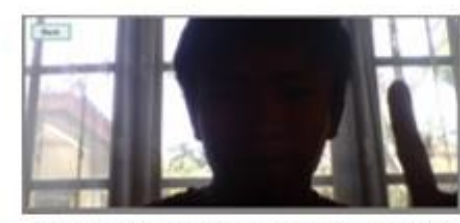

Gambar 3. Tampilan Kamera Tidak Terdeteksi Image Target

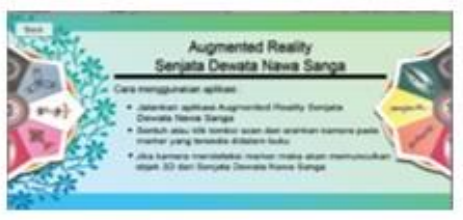

Gambar 5. Tampilan Menu Panduan

digunakan untuk menganalisa dan merancang aplikasi ini antara lain : Use Case Diagram, Activity Diagram, Sequence Diagram, dan Class Diagram. Setelah perancangan sistem maka tahapan selanjutnya adalah perancangan desain antar muka dan perancangan objek 3D, disusul dengan tahapan pembuatan objek 3D dan pembuatan program yang dalam hal ini sudah menggunakan software pembantu seperti Photoshop, Blender, Unity, Vuforia dan sebagainya. Lalu tahapan terakhir adalah implementasi dan pengujian sistem yang bertujuan untuk memeriksa apakah setiap modul yang dimiliki dalam aplikasi AR Senjata Dewata Nawa Sanga berjalan sesuai dengan harapan atau belum. Adapun bagian yang di uji adalah pada proses instalasi aplikasi kedalam perangkat Android, pengujian splash screen, Menu Utama, menu Scan, menu Panduan, menu About me, menu Exit. Berikut merupakan tampilan aplikasi AR Senjata Dewata Nawa Sanga saat dijalankan berserta dengan tabel pengujiannya.
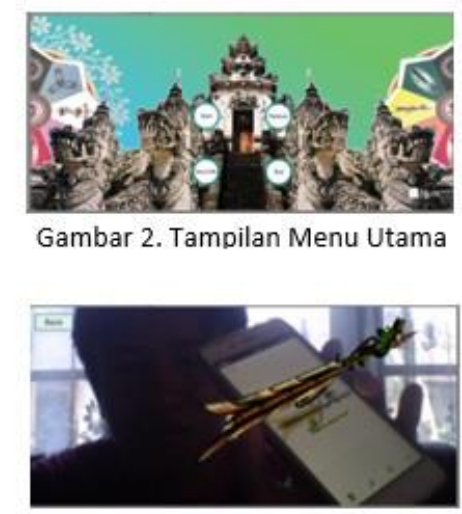

Gambar 4. Tampilan Kamera Mendeteksi Image Target Pada Salah Satu Senjata Dewata Nawa Sañga

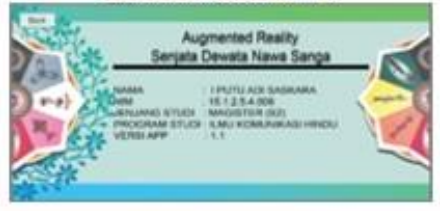

Gambar 6. Tampilan About Me

Augmented Reality Senjata Dewata Nawa Sanga sebagai media pembelajaran dari hasil uji aplikasi yang telah dilakukan memiliki fungsi sebagai berikut : 1) Fungsi Atensi, menarik dan mengarahkan perhatian siswa untuk berkonsentrasi kepada isi pelajaran yang berkaitan dengan makna visual yang ditampilkan, 2) Fungsi Afektif, media visual dapat menggugah emosi dan sikap siswa, 3) Fungsi Kognitif, memperlancar pencapaiaan tujuan untuk memahami dan mengingat informasi atau pesan yang terkandung dalam gambar, 4) Fungsi Kompensatoris untuk 


\begin{tabular}{|c|c|c|c|c|}
\hline No. & Perancangan Proses & $\begin{array}{l}\text { Hasil yang } \\
\text { diharapkan }\end{array}$ & Hasil pengujian & Keterangan \\
\hline 1. & $\begin{array}{l}\text { Pada saat pertama kali } \\
\text { membuka aplikasi. }\end{array}$ & $\begin{array}{l}\text { Menampilkan } \\
\text { splash screen. }\end{array}$ & $\begin{array}{l}\text { Menampilkan } \\
\text { splash screen. }\end{array}$ & Sesuai \\
\hline 2. & $\begin{array}{l}\text { Pada saat splash screen } \\
\text { menghilang. }\end{array}$ & 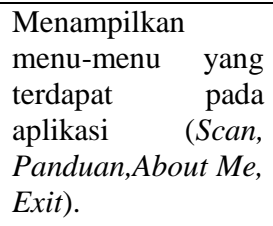 & $\begin{array}{l}\text { Menampilkan } \\
\text { menu-menu yang } \\
\text { terdapat pada } \\
\text { aplikasi (Scan, } \\
\text { Panduan,About } \\
\text { Me, Exit). }\end{array}$ & Sesuai \\
\hline 3. & $\begin{array}{lll}\begin{array}{l}\text { Ketika } \\
\text { diklik. }\end{array} & & \\
\end{array}$ & $\begin{array}{l}\text { Menampilkan } \\
\text { tampilan Camera } \\
\text { dan tombol back. }\end{array}$ & $\begin{array}{l}\text { Menampilkan } \\
\text { tampilan Camera } \\
\text { dan tombol back. }\end{array}$ & Sesuai \\
\hline 4. & $\begin{array}{lr}\text { Ketika } & \text { mengarahkan } \\
\text { Camera } & \text { ke image } \\
\text { target. } & \end{array}$ & $\begin{array}{l}\text { Menampilkan objek } \\
\text { 3D }\end{array}$ & $\begin{array}{l}\text { Menampilkan } \\
\text { objek 3D }\end{array}$ & Sesuai \\
\hline 5. & $\begin{array}{l}\text { Ketika tombol back } \\
\text { pada Camera diklik. }\end{array}$ & $\begin{array}{l}\text { Kembali kehalaman } \\
\text { menu utama }\end{array}$ & $\begin{array}{l}\text { Kembali } \\
\text { kehalaman menu } \\
\text { utama }\end{array}$ & Sesuai \\
\hline 6. & $\begin{array}{l}\text { Ketika menu Panduan } \\
\text { diklik }\end{array}$ & $\begin{array}{l}\text { Menampilkan } \\
\text { halaman cara } \\
\text { menggunakan } \\
\text { aplikasi dan tombol } \\
\text { back. }\end{array}$ & $\begin{array}{l}\text { Menampilkan } \\
\text { halaman cara } \\
\text { menggunakan } \\
\text { aplikasi dan tombol } \\
\text { back. }\end{array}$ & Sesuai \\
\hline 7. & $\begin{array}{l}\text { Ketika tombol back } \\
\text { pada menu Panduan } \\
\text { diklik. }\end{array}$ & $\begin{array}{l}\text { Kembali kehalaman } \\
\text { menu utama }\end{array}$ & $\begin{array}{l}\text { Kembali } \\
\text { kehalaman menu } \\
\text { utama }\end{array}$ & Sesuai \\
\hline 8. & $\begin{array}{l}\text { Ketika tombol About } \\
\text { me diklik. }\end{array}$ & $\begin{array}{l}\text { Menampilkan } \\
\text { halaman informasi } \\
\text { dari pembuat } \\
\text { program dan tombol } \\
\text { back. }\end{array}$ & $\begin{array}{l}\text { Menampilkan } \\
\text { halaman informasi } \\
\text { dari pembuat } \\
\text { program dan } \\
\text { tombol back.. }\end{array}$ & Sesuai \\
\hline 9. & $\begin{array}{l}\text { Ketika tombol back } \\
\text { pada About me diklik. }\end{array}$ & $\begin{array}{l}\text { Kembali kehalaman } \\
\text { menu utama. }\end{array}$ & $\begin{array}{l}\text { Kembali } \\
\text { kehalaman menu } \\
\text { utama. }\end{array}$ & Sesuai \\
\hline 10. & $\begin{array}{l}\text { Ketika tombol Exit } \\
\text { diklik. }\end{array}$ & Menutup aplikasi. & Menutup aplikasi. & Sesuai \\
\hline
\end{tabular}

mengakomodasikan siswa yang lemah dan lambat menerima dan memahami isi pelajaran yang disajikan dengan teks atau disajikan secara verbal (Munadi Wahyudi, 2003).

\section{Augmented Reality Senjata}

Dewata Nawa San ga sebagai media pembelajaran dari hasil uji aplikasi yang telah dilakukan memiliki fungsi sebagai berikut : 1) Fungsi Atensi, menarik dan mengarahkan perhatian siswa untuk berkonsentrasi kepada isi pelajaran yang berkaitan dengan makna visual yang ditampilkan, 2) Fungsi Afektif, media visual dapat menggugah emosi dan sikap siswa, 3) Fungsi Kognitif, memperlancar pencapaiaan tujuan untuk memahami dan mengingat informasi atau pesan yang terkandung dalam gambar, 4) Fungsi Kompensatoris untuk mengakomodasikan siswa yang lemah dan lambat menerima dan memahami isi pelajaran yang disajikan dengan teks atau disajikan secara verbal (Munadi Wahyudi, 2003). Sebagai komunikasi pendidikan Augmented Reality Senjata 
Dewata Nawa San ga berfungsi sebagai media (saluran) komunikasi antara guru dengan siswanya sehingga terjadi proses belajar yang efektif. Adapun dampak yang ditimbulkan dari penggunaan Augmented Reality Senjata Dewata Nawa San ga ini adalah : 1) meningkatkan minat belajar siswa, 2) meningkatkan hasil belajar siswa yang terbukti dari hasil penelitian kelas kontrol dan kelas experimen sebelum perlakuan dan setelah perlakuan yang ditampilkan pada gambar 7 dan gambar 8 sebagai berikut :
IImu Komunikasi Pendidikan Agama Hindu meliputi : 1) Fungsi Atensi, 2) Fungsi Afektif, 3) Fungsi Kognitif, 4) Fungsi Kompensatoris. Media pembelajaran dapat memenuhi tiga fungsi utama apabila media itu digunakan untuk perorangan, kelompok, atau kelompok pendengar yang besar jumlahnya, yaitu : 1) Memotivasi minat atau tindakan, 2) Menyajikan informasi, 3)Memberi instruksi dan dari semua fungsi diatas fungsi yang paling penting adalah untuk mempermudah guru dan

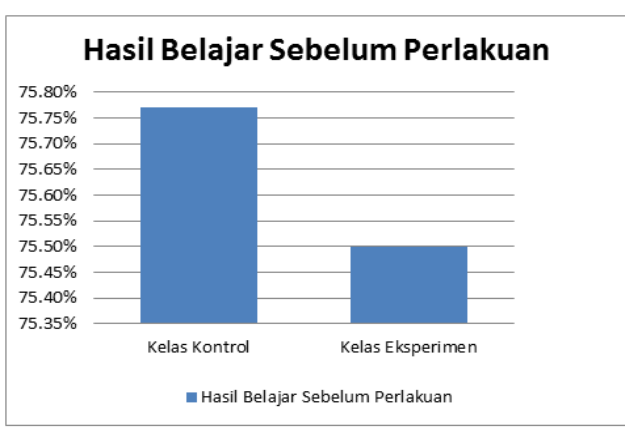

PENUTUP

Simpulan

Saran

Membangun sebuah aplikasi Augmented Reality Senjata Dewata Nawa San ga berbasis android dapat menggunakan beberapa aplikasi software yang sudah ada diantaranya Blender, Unity, Vuforia, Photoshop, dan sebagainya. Aplikasi Augmented Reality Senjata Dewata Nawa Sanga ini mempunyai spesifikasi perangkat keras yaitu.

Perangkat : Jenis gadget dengan sistem operasi android dengan versi minimal 4.2.2 Jelly Bean dan maksimal versi 4.4 Kitkat.

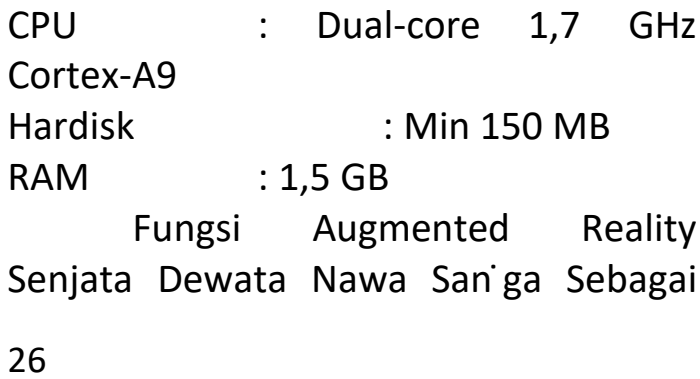

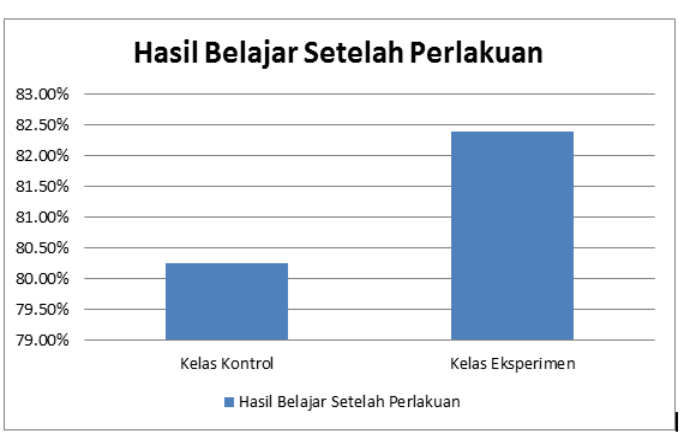

siswa dalam berkomunikasi khususnya dalam hal pembelajaran. Sehingga akan terjadi proses belajar mengajar yang mengakibatkan peserta didik akan memahami hal yang diberikan pendidik atau guru.

Dampak Augmented Reality Senjata Dewata Nawa San ga meliputi 1) meningkatkan minat belajar siswa, 2) meningkatkan hasil belajar siswa yang sudah terbukti positif karena hasil belajar kelas eksperimen lebih tinggi di bandingkan hasil belajar kelas kontrol setelah perlakuan dengan hasil persentase $80.25 \%$ untuk kelas kontrol dan $82.4 \%$ untuk kelas eksperimen.

\section{DAFTAR PUSTAKA}

Adi Nugroho. 2009. "Rekayasa Perangkat Lunak Menggunakan UML dan Java Edisi 1". Yogyakarta : Andi Publisher. 
Agus Suprijono. 2009. "Cooperative Learning, Teori \& Aplikasi PAIKEM". Surabaya: Pustaka Pelajar

Andria Kusuma Wahyudi, Ridi Ferdiana, Rudi Hartanto. 2013. "ARca : Perancangan Buku Interaktif Berbasis Augmented Reality pada Pengenalan dan Pembelajaran Candi Prambanan dengan Smartphone Berbasis Android". Jurnal Teknologi Informasi, Teknik Electro, Universitas Gadjah Mada.

Anggi Andriyadi. 2011, "Penerapan Augmented Reality Pada Brosur Untuk Media Periklanan Mobil Secara Virtual ". Jurnal Teknologi Informasi.

Anggi Andriyadi. 2012, “Augmented Reality With ARToolkit" Jakarta : NulisBuku.com.

Burhan. M. 2007."Penelitian Kualitatif: Komunikasi, Ekonomi, Kebijakan Publik, dan Ilmu Sosial Lainnya". Jakarta : Kencana Prenada Media Group.

Darmawan Gede. 2015, "Nawa Dewata", [Badung 24-Maret-2017]. https://www.mindmeister.com/108 278304/nawa-dewata.

Djam'an Satori dan Aan Komariah. 2013. "Metodologi Penelitian Kualitatif". Bandung : Alfabeta.

Feby Zulham Adami, Cahyani Budihartanti. 2016 "Penerapan Teknologi Augmented Reality pada Media Pembelajaran Sistem Pencernaan Berbasis Android". Jurnal Teknik Komputer AMIK BSI.

Fernando.M. 2013 "Membuat Aplikasi Android Augmented Reality Menggunakan Vuforia SDK dan Unity".

Hasan, M. Iqbal. 2002. "Pokok-Pokok Materi Metodologi Penelitian \&
Aplikasinya". Bogor: Ghalia Indonesia.

Hendi Hendratman. 2015. "The Magic of Blender 3D Modelling". Informatika. Joseph A. DeVito. 2010. "Komunikasi Antarmanusia" (Edisi 5), Karisma Publishing.

Margono. 2005. "Metode Penelitian Pendidikan. Jakarta" : Rineka Cipta,

Mulyana, Deddy. 2008. "Ilmu Komunikasi Suatu Pengantar". Bandung : PT Remaja Rosdakary

Munadi, Wahyudi. 2003. "Media Pembelajaran". Jakarta: Gama persada.

Moleong, Lexy J.2012. "Metodologi Penelitian Kualitatif", Bandung. Remaja Rosdakarya.

Nasikun. 2004. "Sistem Sosial Indonesia". Jakarta: Raja Grafindo Persada.

Narbuko,Cholid., dan Achmadi, Abu. 2008. "Metodologi Penelitian". Jakarta: PT. Bumi Aksara.

Rickman Roedavan. 2016."Unity Tutorial Game Engine Edisi

Revisi".Informatika

Ritzer George. 2004."Teori Sosiologi Modern". Jakarta : Prenada Media Group

Sabri, A. 2005, "Strategi Belajar Mengajar Micro Teaching, Quantum Teaching", Jakarta.

Sugiyono 2010 "Metode Penelitian Kuantitatif Kualitatif \& RND". Bandung : Alfabeta

Sugiyono.2003. "Metode Penelitian Administrasi", Bandung: Alfabeta,

Sujarweni, Wiratna.2014. "SPSS Untuk Penelitian". Yogyakarta, Pustaka Baru Press.

Supardi.2006. "Metodologi Penelitian, Mataram" : Yayasan Cerdas Press. 
Syah, Muhibbin.1998, "Psikologi Suatu

Pendekatan Baru", Bandung:

Remaja Rosda Karya.

Titib I Made , 2003, "Teologi Dan Simbol-

Simbol Dalam Agama Hindu",

Paramita Surabaya.

T. Raka Joni. 1984. "Strategi Belajar-

Mengajar, Suatu Tinjauan

Pengantar". Jakarta.

Uma Sekaran. 2006. "Metodologi

Penelitian. Jakarta" : Salemba

Empat. 